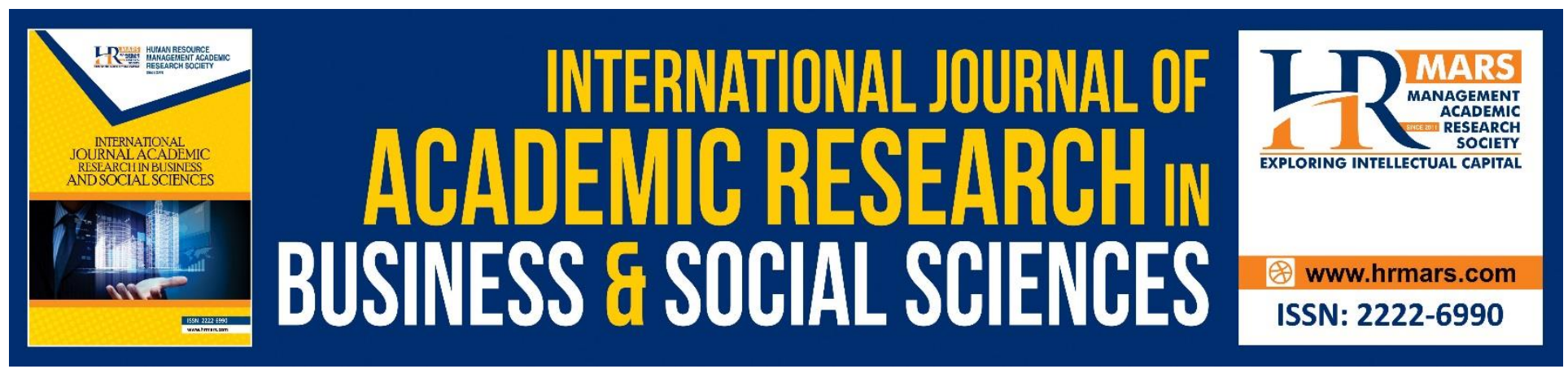

\title{
Effect of E-Financial Documentation and Statements on Operating Costs in Universities in Kenya.
}

Majory Nyaga, Riro Kamau, David Kiragu

To Link this Article: http://dx.doi.org/10.6007/IJARBSS/v10-i8/7502

DOI:10.6007/IJARBSS/v10-i8/7502

Received: 16 May 2020, Revised: 14 June 2020, Accepted: 09 July 2020

Published Online: 14 August 2020

In-Text Citation: (Nyaga et al., 2020)

To Cite this Article: Nyaga, M., Kamau, R., \& Kiragu, D. (2020). Effect of E-Financial Documentation and

Statements on Operating Costs in Universities in Kenya. International Journal of Academic Research in

Business and Social Sciences, 10(8), 75-92.

Copyright: (C) 2020 The Author(s)

Published by Human Resource Management Academic Research Society (www.hrmars.com)

This article is published under the Creative Commons Attribution (CC BY 4.0) license. Anyone may reproduce, distribute, translate and create derivative works of this article (for both commercial and non-commercial purposes), subject to full attribution to the original publication and authors. The full terms of this license may be seen

at: http://creativecommons.org/licences/by/4.0/legalcode

Vol. 10, No. 8, 2020, Pg. 75 - 92

http://hrmars.com/index.php/pages/detail/IJARBSS

JOURNAL HOMEPAGE

Full Terms \& Conditions of access and use can be found at http://hrmars.com/index.php/pages/detail/publication-ethics 


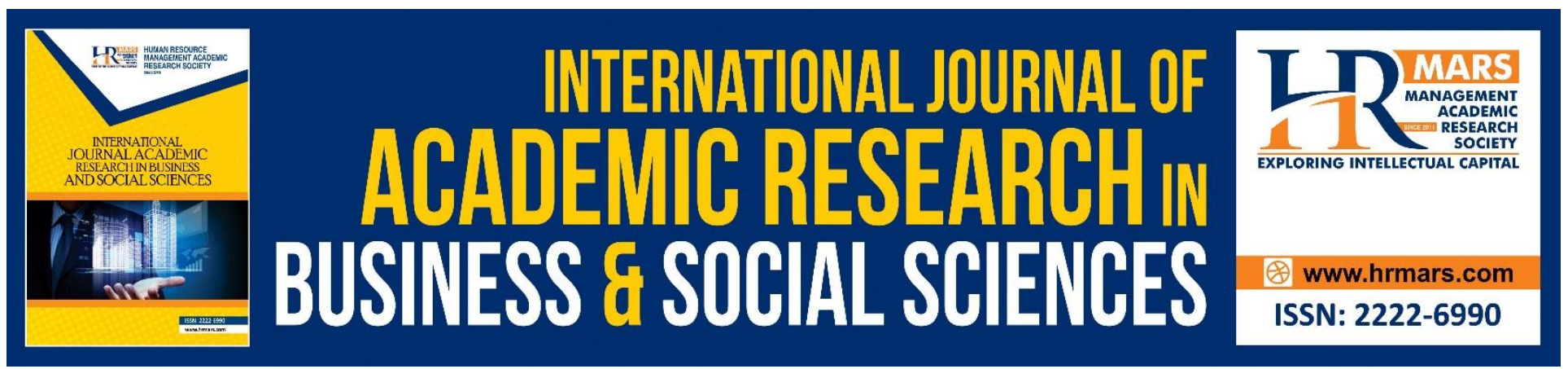

\title{
Effect of E-Financial Documentation and Statements on Operating Costs in Universities in Kenya.
}

\author{
Majory Nyaga ${ }^{1}$, Riro Kamau $\mathrm{PhD}^{2}$, David Kiragu $\mathrm{PhD}^{3}$ \\ ${ }^{1}$ MBA Thesis, Dedan Kimathi University of Technology, 2,3Senior Lecturer, Dedan Kimathi University \\ of Technology
}

\begin{abstract}
Institutions globally have embraced electronic systems of managing documents and generation of financial statements ranging from maintenance of ledgers, extraction of the trail balance and automated income statement and statement of financial position. This study sought to analyze the effect of e-financial documentation and statements on operating costs in universities in Kenya. The study was guided by theory of reasoned action and technology acceptance model. The target population was 80 employees drawn from 8 universities, four public universities and four private universities operating in Mount Kenya region. Census was used to collect the data from target population. A self-administered semi-structured questionnaire was distributed to the target population. A total of 71 questionnaires were returned giving a response rate of $88.75 \%$. Statistical package was used to undertake descriptive and inferential statistical analysis. Descriptive analysis was done using both means and standard deviations. Bivariate linear regressions were used to assess the effect of e-financial documentation and statements on operating costs. Model R2, ANOVA Statistics ( $F$ Statistic and associated $p$-value) and regression coefficients (Beta and associated $p$-value) were generated and interpreted. The Bivariate results indicated that online financial documentation have a significant effect on the operating cost of universities. Electronic financial statements had an insignificant effect on operating costs of universities. This study concludes that online financial documentation affects organization costs in the universities. The study recommends the need to sensitize management of universities and other organizations on the importance of electronic financial services because they could reduce operating costs.
\end{abstract}

Keywords: Electronic Financial Documentation, Electronic Financial Statements, Operating Costs.

\section{Introduction}

\section{Background of the Study}

Bushman and Smith (2001) assert that a fundamental objective of governance research in accounting is to provide evidence on the extent to which information provided by financial accounting systems mitigate agency problems due to the separation of managers and outside investors, facilitating the efficient flow of scarce human and financial capital to promising investing opportunities. Osmond (2011) argued that manual accounting has been in practice since time in memorial and it's still being 
INTERNATIONAL JOURNAL OF ACADEMIC RESEARCH IN BUSINESS AND SOCIAL SCIENCES Vol. 10, No. 8, 2020, E-ISSN: 2222-6990 @ 2020 HRMARS

practiced to-date. Manual accounting implies that employees perform the whole accounting cycle manually on a periodic basis: they calculate trial balances, journalize transactions, and prepare financial statement reports and other routines which of course it takes much time, resources and effort in large organizations than electronic financing. World Bank (2000) noted that electronic accounting began around 1930 with adding machines and basic computers performing computerized mathematical functions in early 1930s. By the end of 1990s, e-finance technologies affected all aspects of the business of banking and financial intermediation.

Allen, McAndrews, and Stratran (2002) defined e-finance as the provision of financial services and markets using electronic communication and computation. Shahrokhi (2008) defined electronic financial transaction as a transaction that depends on the internet or a similar network to which households or non-financial enterprises have access to bank. The key drivers of e-finance include technology, globalization, regulations etc. That e-finance has great potential to improve the quality and scope of financial services and expand opportunities for covering trading risks and can widen access to financial services for a much greater set of retail and commercial clients by offering more cost-effective services.

Robinson (2000) argued that the cost of an electronic financial transaction is dramatically less when done online as compared to when done manually. Sharma and Ahuja (2014) observed that operating costs are the expenses which are related to the operations of a business, or to the operation of a device, component, and piece of equipment or facility. They are the cost of resources used by an organization just to maintain its existence. They include expenditures for staffing, hardware maintenance, electricity, software procurement, storage rental and security and fall into two categories, fixed costs and variable costs. That operating costs are not unique to any organization but may vary from profit to nonprofit making.

Bamford (2006) asserts that fixed operating costs are expenses that tend to remain the same whether the business or device is inactive or operating at full capacity. Examples of such expenses include employee salaries and rent of premises; leasing fees amongst others while variable are those that vary with level of production. Operating costs in public universities comprise of registration costs while admitting new students, rent of premises, water, electricity, stationery, transportation costs, processing the salaries paid to workers (the basic pay, allowances of all kind, bonus, overtime pay and all other costs related to employees), training and development of staff, repair and maintenance costs of fixed assets, depreciation of fixed assets, and so on.

Frantz (2002) observed that due to the decreased government funding and with the increasing in expectation by stakeholders, universities are currently under pressure to deliver higher quality educational services for lower costs. For these reasons, ERP systems can be very appealing to HEls as a potential route to meeting these standards. King, Kvavik, and Voloudakis (2002) argued that some of the top reasons universities adopt ERP solutions are to replace legacy systems, improve customer service, and transform enterprise processes, correct year 2000 problems, modernize computer systems, improve administration, maintain competitiveness, increase operating efficiency, and adhere to regulatory compliance. 
Most universities today both private and public have embraced e-finance through adoption of enterprise resource planning (ERP) system mainly aimed at assist them reduce costs as well as improve the quality of service delivery. Sadagopan (2003) asserts that some of the most ordinary accounting processes, which are incorporated in an ERP system, include: general ledger, accounts receivable, accounts payable, financial control, asset management, funds flow, cost centers, profit centers, profitability analysis, order and project accounting, product cost accounting, and performance analysis. Electronic services rendered by most learning institutions include registration of students on-line, e-learning mode, e-bills, e-interdepartmental communications, e-checks, online banking, EFT payrolls, and e-books of accounts amongst other services.

Maggiotto and Rocco (2000) suggested that the degree to which emerging markets will be able to adopt Internet technologies will depend on their telecommunications infrastructure. Access to the Internet is much lower in emerging markets than in developed countries. He suggested that reforms to make telecommunications more competitive deserve priority.

The most immediate impacts will also differ by market. Allen (1999) noted that in especially the developing countries, where access to and the quality of financial services is limited, e-finance and globalization offers many important opportunities. That e-finance has great potential to improve the quality and scope of financial services and expand opportunities for trading risks, and can widen access to financial services for a much greater set of retail and commercial clients by offering more cost-effective delivery of services.

Bailey (2004) is of the opinion that the low efficiency and quality of financial services and the skewed profile of users favor migration toward e-finance in many emerging markets. In some emerging markets online brokerage is already on par with that in developed countries. In some countries a lack of regulatory barriers and initial markets has made new entry across a spectrum of services attractive. In other countries entry has been more specialized. Berger (2000) asserts that e-finance will require a reassessment of the approach to financial sector development. E-finance allows much easier access to global capital and financial service providers.

Miriam (2000) argued that for many countries, e-finance offers opportunities to quickly widen access to and improve financial services. Achieving such gains will require that emerging markets give far greater priority to improving the framework for financial and other information, modernizing and strengthening their legal systems, and improving technology-related infrastructure such as telecommunications. Many of the recent trends in financial services have been driven by the globalization of financial markets. Financial services have also been reshaped by technological and structural changes, including the lowering of regulatory barriers. The above theories are mainly based on businesses established for profit making but there is no study so far done on the effect of electronic financial services on operating costs in a university context.

\section{Statement of the Problem}

Operating costs are a big hindrance to the achievement of the main objective of any firm. With the increased enrolment of government sponsored students in public universities and reduced capitation to the universities by the government, universities are faced with a challenge of how to cope with 
INTERNATIONAL JOURNAL OF ACADEMIC RESEARCH IN BUSINESS AND SOCIAL SCIENCES Vol. 10, No. 8, 2020, E-ISSN: 2222-6990 @ 2020 HRMARS

this high cost of operation. To mitigate this problem universities themselves have tried to adopt some cost reduction measures such as adoption of Enterprise Resource Planning(ERP) system in their operations but there is no study so far indicating how ERP and e-financing affects their operating costs. The big question is whether the adoption of electronic financial services by universities such as online registration of students and communications, online financial documentation and online financial statement has had any impact on their operating costs. A review of the existing literature on electronic financial services indicates that there is no comprehensive study so far outlining the effects of electronic financial services on organizational operating costs. This study focus on the effect of e-financial documentation and statements on operating costs in universities in Kenya.

\section{Objectives of the Study}

The study was aimed at achieving the following objectives

- To investigate the effect of electronic financial documentation on operating costs of univesities

- To examine the effect of e-financial statements on operating costs of univesities

\section{Significance of the Study}

This study will benefit the universities in Kenya since operating costs are not unique to one university but cuts across all types of universities both public and private. With the knowledge of how e-financial services affect the operating costs of an enterprise, the university management can reduce its costs and subsequently increase its surplus especially at such a time when public universities are being faced with reduced government funding. The information will also serve as reference material for policy makers, implementers, scholars, and researchers. The employees of universities will also benefit because with reduced operating costs, the surplus of the enterprise would increase salaries and wages and other improve other working conditions. The study at hand contributes to previous research in that it seeks to promote greater understanding of the importance of electronic finance services and its contribution to operating costs reduction.

\section{Literature Review \\ Theoretical review \\ Theory of Reasoned Action (TRA)}

Ajzen and Fishbein (1980) asserts that a person's attitude toward a behavior consists of belief that particular behavior leads to a certain outcome and an evaluation of the outcome of that behavior. If the outcome seems beneficial to the individual, he or she may then intend to or actually participate in a particular behavior. Whether or not a person participates or intends to participate in any behavior is influenced strongly by the people around them. These people may include friends or a peer group, family, co-workers, church congregation members, community leaders and even celebrities. Ultimately, one's attitude toward a behavior can lead to an intention to act (or not to act as the case may be).Others will never move past the intention stage.

This theory is connected to my study in that, effectiveness of electronic financial services depends on the attitude of employees towards use of computerized accounting and more so the benefits they expect from the system. That peer pressure also affects the performance other employees. If employees influenced one another to the view e-financing as unbeneficial to them they will frustrate 
INTERNATIONAL JOURNAL OF ACADEMIC RESEARCH IN BUSINESS AND SOCIAL SCIENCES Vol. 10, No. 8, 2020, E-ISSN: 2222-6990 @ 2020 HRMARS

it in whatever possible manner thus instead of electronic financing reducing costs it may increase costs instead.

In its simplest form, the TRA can be expressed as the following equation:

$B I=(A B) W_{1}+(S N) W_{2}$

Where:

$\mathrm{BI}$ = behavioral intention

$(A B)=$ one's attitude toward performing the behavior

$\mathrm{W}=$ empirically derived weights

$\mathrm{SN}=$ one's subjective norm related to performing the behavior (Hale, 2002)

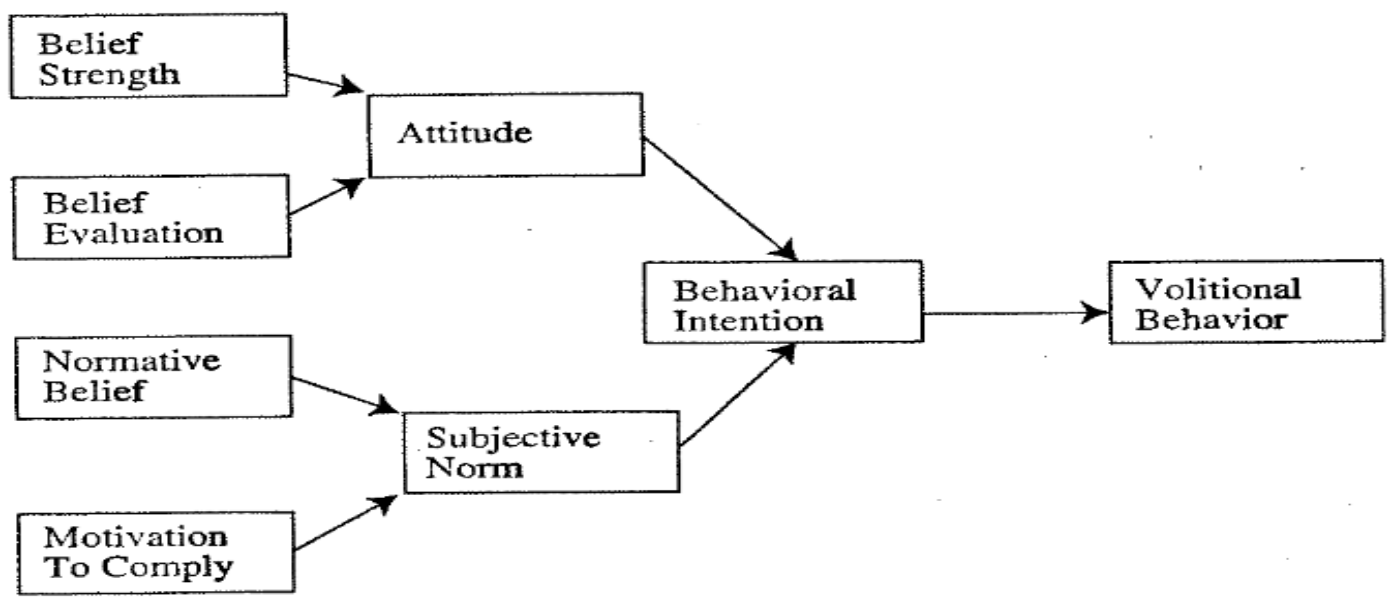

Figure 1: Theory of Reasoned Action (Ajzen and Fishbein (1980)

\section{Technology Acceptance Model (TAM)}

Technology Adoption Model propounded by Davis $(1985,1989)$ has been the foundation of many technology adoption and diffusion research and it is rooted in the Theory of Reasoned Action (TRA). As per TAM, the two important independent variables of actual use of technology are: Perceived ease of use, defined as 'the degree to which a person believes that using a particular system would be free of effort' Perceived usefulness, defined as 'the degree to which a person believes that using a particular system would enhance his or her performance'. TAM was developed to explain and predict particular IT usages. However, this particular model has been used by many researchers in studying adoption and diffusion of various IS technologies.

Davis defined perceived use-fullness as' the degree to which a person believes that using a particular system would enhance his or her job performance " and defined perceived ease of use as' the degree to which a person believes that using a particular system would be free of effort." TAM postulated that computer usage is determined by a behavioral intention to use a system, where the intention to use the system is jointly determined by a person's attitude toward using the system and its perceived usefulness.

This theory is connected to my study in that effective use of e-financing depends on whether employees perceive the use of electronic financing will enhance performance of their tasks and the 
INTERNATIONAL JOURNAL OF ACADEMIC RESEARCH IN BUSINESS AND SOCIAL SCIENCES Vol. 10, No. 8, 2020, E-ISSN: 2222-6990 @ 2020 HRMARS

ease their work. If they think e-financing will actually make their work difficult they will work against the system.

K. Amoako-Gyampah, A.F. Salam/Information \& Management 41 (2004) 731-745

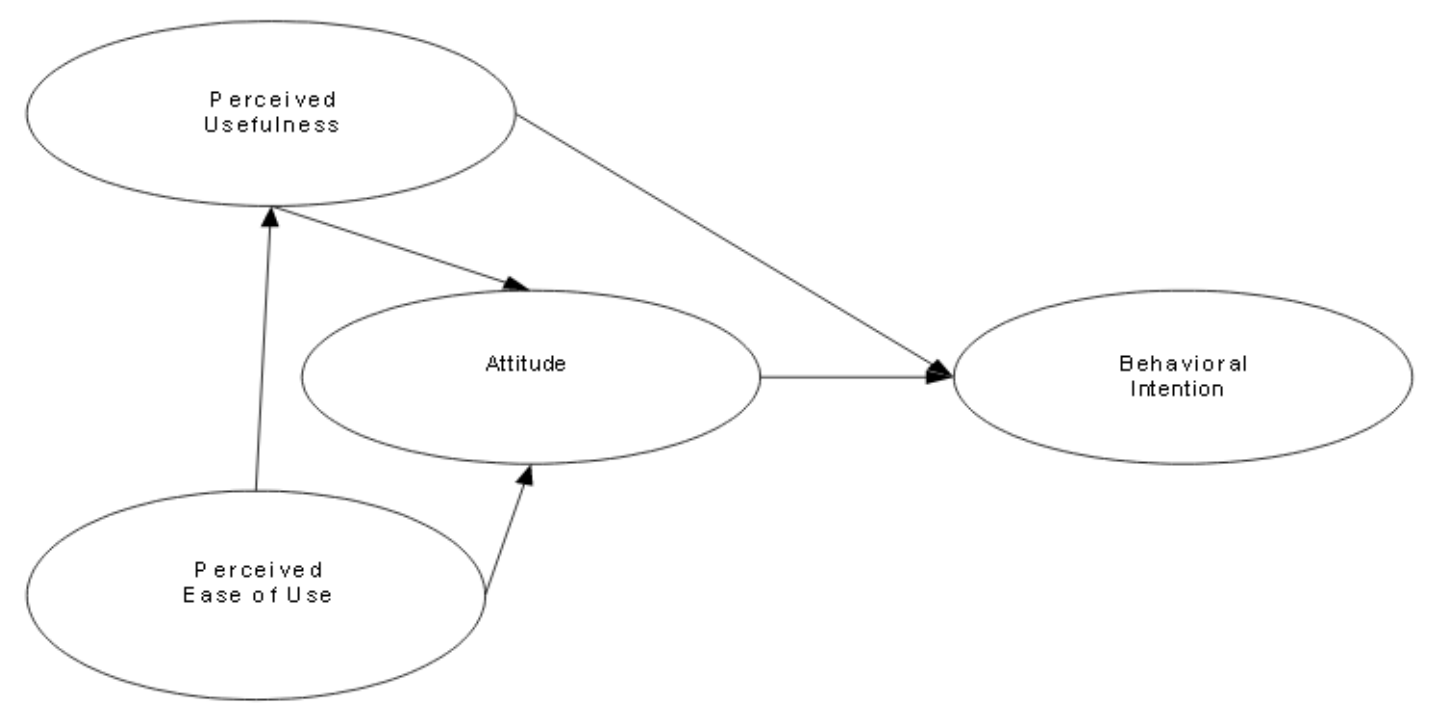

Figure 2: Technology Acceptance Model (Davis 1985, 1989)

\section{Empirical Review}

\section{Enterprise Resource Planning}

Swartz and Orgil (2001) defined Enterprise Resource Planning (ERP) as a software solution that integrates business functions and data into a single system to be shared within a company. That although ERP originated from manufacturing and production planning systems it expanded its scope in the 1990's to other "back-office" functions such as human resources, finance and production planning. Nah and Kuang (2001) argued that the major goal of ERP is to increase operating efficiency by improving business processes and decreasing costs.

Dillard and Yuthas (2006) stated that most multinational firms are using ERP and that more small and midsize companies have begun to adopt ERP. That although ERP promises to benefit companies not all ERP implementations have yielded successful outcomes. Scott and Vessey et al., (2000) argued that ERP implementations have sometimes failed to achieve the organization's targets and desired outcomes. Much of the research reported that the failure of ERP implementations was not caused by the ERP software itself, but rather by a high degree of complexity from the massive changes ERP causes in organizations

Rabaa'i (2009) conducted a study on ERP Systems in the Higher Education Sector: A descriptive Case Study found out that in 60 to 80 percent of higher education contexts, ERP implementation failed to meet expected outcomes and results of implementation were found unsatisfactory Hunton (2003) compared the Financial Performance of ERP adopters and Non-Adopters. The total sample size comprised 123 companies (63 ERP adopters and 60 Non-adopters). They compared the results of ROA, ROS, ROI and ATO in different periods of ERP pre-implementation ( $t-3$ to $t-1$ ) and Post 
INTERNATIONAL JOURNAL OF ACADEMIC RESEARCH IN BUSINESS AND SOCIAL SCIENCES Vol. 10, No. 8, 2020, E-ISSN: 2222-6990 @ 2020 HRMARS

implementation ( $t+1$ to $t+3$ ) for 3 years' time. The study found that that return on assets (ROA), return on investment (ROI), and asset turnover (ATO) were significantly better over a 3-year period for adopters, as compared to non-adopters.

Maroofi (2012) investigated the impact of investment in Enterprise Systems (ERP \&SCM) on long run stock price and profitability performance. Author used a big sample size of 978 firms 558 for the investment announcement in ERP and 420 for SCM there are two types of samples: the firms that have just plan or stared implementing ERP or SCM System and second the firms have completed the implementation of ES (ERP, SCM). He used two different methodologies to find the effect: first methodology to find the effect of investment in Enterprise System on long run stock price and profitability and the second to measure the performance during the period of implementation of ERP system and post implementations performance the methodology as used by difference researchers for the measurement of the same thing. Maroofi found that ERP Improves abnormal return of the firm while ERP does not improve stock returns. The author also found that some firms have positive impact of Investment in Enterprise System on financial performance while others have negative due to high implementation cost and other implementation problems. On the other hand SCM has positive impact on stock returns.

Sale (2005) compared the actual with the expected performance to examine the impact of ERP on financial accounting measures. Author used case study of Taxas Instruments, Inc. where ERP system is functional. Author Collected secondary financial data of ROI, ROE, ROA, Employees, Productivity and Inventory from 1998 to 2002. The study found negative values of ROE, ROI, and ROA after two years of implementation of ERP system while study also found increase in organizational productivity post implantation period. Author concluded that ERP system do not improved financial performance immediately after its installation in organization. They concluded that company may not be improving the financial performance immediate after ERP System implementation.

Bohorquez and Esteves (2008) investigated the impact of ERP system on SME's productivity. Authors used Cobb-Douglas production function to measure the impact of ERP implementation on SME's productivity. Authors used different indicators of productivity to compare the pre and post implementation of ERP system in SME's and used SME's Size as a moderating variable between ERP impact and SEM's productivity level. They found that SME's size changes the impact of ERP on productivity level and they suggested the practitioners of ERP that they should consider the size of organization for the best results after deploying ERP system. They also found the positive impact of number of employees while negative impacts of income on SME's productivity while the negative impact of ERP usage on organizational productivity.

Leech and Grabski (2007) identified the relation of ERP system on financial performance of the business. Authors selected data from different data bases of disclosed ERP adoption from 1980 to 1997. They found no significant change in cost or administrative and selling expenses in the post implementation period of ERP system. Leech and Grabski (2007) argued that ERP system effect positively on firm's performance in two way: it reduce the cost by improving efficiency of business processes in a computerized way and it enhance decision making ability by providing accurate information in time. 


\section{Electronic Financial Documentation}

Gaffey (2009) argued that Electronic health records (EHRs) are here to stay and their use is expected to grow significantly in the future. It is incumbent on risk managers to ensure their use does not inhibit good provider-to-patient communication. Providing education and strategies on how to make the patient encounter meaningful while the provider uses an EHR may increase patient satisfaction and may contribute to a favorable professional liability loss experience. Risk managers also need to have an understanding of the capabilities of each specific EHR system in the facility, the implications of the ability to cut-and-paste information from one provider entry to another, and knowledge of how to control the risk that comes with both copying for-ward and delayed EHR documentation

Miller and Sim (2004) found that there are a few disadvantages to electronic health records that come into play with this new technology. One of the largest and most concerning issues is the possibility of losing records. A potential reason for this would be if a vendor company was to suddenly and forcefully close down. One would hope all the records and information held within that company would be stored and properly backed up, but it is doubtful. That loss of the records would result into disappointing many loyal patrons and ultimately having no concrete explanation for them as to why their records are lost. Such an enormous mishap would have a damaging effect to the business, resulting in a loss of customers, and eventually closure of the business.

\section{E-financial Statements}

Barata et al (2001) found out that good practice for the management of financial records in computerized systems and analyses the optimal ways of creating the linkages between the manual (i.e. paper-based) and computerized parts of systems and provides tools to evaluate and monitor the performance of record keeping systems. It focuses on the transaction records that are used by and produced as a result of financial management functions, in particular the accounting function. Normally, these are required for audit purposes. Relevant administrative, operational and policy records are also taken into account, including tenders, contracts, accounting directives, loan agreements and so on.

Stephenie Meyer (2008) asserts that financial institutions and all other institutions, whoever needs to send you a statement monthly, quarterly, or annually, are moving towards eliminating paper statements and encouraging customers to subscribe or access statements online thus reduce operating costs. That some banks charge for paper statements upon switching from paper statements to online statements because they are easy to manage and keep organized. That paper statements cause pilling of statements and sometimes failure to miss deadlines because some statements go missing or were underneath other statements. Online statements make life easier.

\section{Conceptual Framework}

The frame work presented in Figure 3 represents the relationship between the dependent variable and the independent variables. In addition, it indicates how the researcher will measure the independent variables. The operating costs were measured using parameters such as stationery, manhours, and transportation cost and storage space. 
INTERNATIONAL JOURNAL OF ACADEMIC RESEARCH IN BUSINESS AND SOCIAL SCIENCES

Vol. 10, No. 8, 2020, E-ISSN: 2222-6990 @ 2020 HRMARS

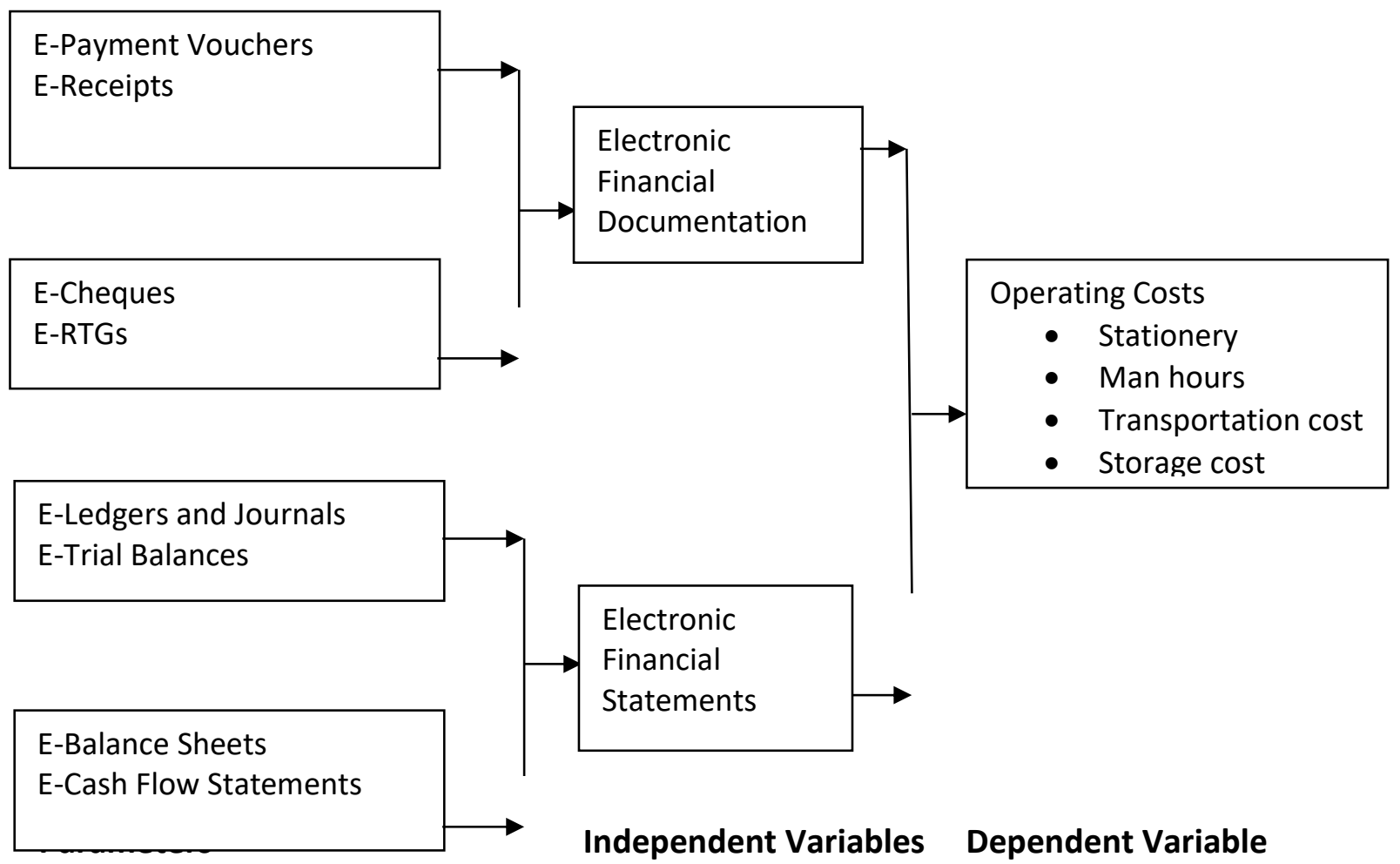

Figure 3: Conceptual Framework

\section{Research Methodology \\ Research Design}

Ogula (2008) defines a research design as a plan structure and strategy of investigation conceived so to obtain answers to research questions. The study adopted a descriptive survey design. According to Orodho (2009), descriptive survey design is a technique in which detailed information concerning a social phenomenon is gathered by posing questions to respondents. The design is appropriate in collecting, classifying, analyzing, comparing and interpreting data (Kombo \& Tromp, 2006). In the current study the target population was constituted by 80 employees from the eight universities (four private and four public) who are engaged in financial transactions in their universities in Mount Kenya region. Ten respondents from every university were purposively selected who were comprised of five heads of section in the finance department, and five heads of departments; procurement, Human resource, ICT, Maintenance and Medical departments. Primary data was collected through the use of questionnaire. Borg and Gall (2003) observed that questionnaires are used to obtain descriptive information from a larger group. They also ensure objectivity due to its confidentiality. Questionnaires are commonly used to collect important information about a population (Mugenda \& Mugenda, 2008).

\section{Reliability and Validity of the Data Collection Instruments}

Reliability is a measure of the degree to which a research instrument yields consistent results after repeated trials; Nsubuga (2000). Reliability enhances the dependability, accuracy, clarity and adequacy of the instruments. To enhance reliability of the instruments, a pilot study was conducted among employees who did not form part of the respondents in the main study. Test re-test method 
was used to examine the reliability of the instruments. Similar questions were administered and repeated after one week. The responses were summarized and compared to the earlier ones. The relationship between the two tests in the pilot study was calculated using the cronbach alpha coefficient. To ascertain the validity of the data collection instruments the questionnaires were given to the supervisors to critique it. The supervisors suggested the areas that needed changes in order to establish the content validity of the instrument. After the piloting the questions in the questionnaire were which were found not clear were reframed for clarity.

\section{Data Analysis and Presentation}

According to Marshal and Rossman (2011) data analysis is the process of bringing order, structure and interpretation to the mass of collected data. The collected data, with the aid of questionnaire was systematically organized specifically to facilitate analysis. Statistical package was used to undertake descriptive and inferential statistical analysis. Descriptive analysis was done using both means and standard deviations. Bivariate linear regressions were used to assess the effect of efinancial documentation and statements on operating costs. Model R2, ANOVA Statistics (F Statistic and associated $p$-value) and regression coefficients (Beta and associated $p$-value) were generated and interpreted. Multiple linear regression was used to assess the combined effect of electronic financial services on operating cost in universities operating. The multiple linear regression model was; $Y=\beta O+\beta_{1} X_{1}+\beta_{2} X_{2}$

Where:

$$
\begin{aligned}
& Y=\text { Operating cost } \\
& \beta_{0}=\text { Autonomous factors } \\
& \beta_{1, \beta 2} \beta_{3}, \beta_{4}=\text { are beta coefficients } \\
& X_{1}=\text { Electronic financial documentation } \\
& X_{2}=\text { Electronic financial statements }
\end{aligned}
$$

The findings of the study were presented with the aid of bar charts, frequency tables, percentages, standard deviation and mean score and then discussed as per the objectives of the study.

\section{Research Findings and Discussion Response Rate}

The data that was analyzed was obtained from 80 respondents out of which 71 respondents filled in the questionnaires and returned. This was $88.75 \%$ of the target group.

\section{Education Level of Respondents}

This study sought to establish the level of education of respondents. The level of education was paramount in the study to enable the researcher to establish whether the respondent were able to articulate issues under consideration. The results are presented in Table 4.1. The study revealed that majority of the people working in the universities as head of sections in finance department and other heads of departments are post graduates. Out of the 71 respondents $62 \%$ were post graduates, $25.4 \%$ were graduates, $7 \%$ diploma holders and only $5.6 \%$ were certificate holders. 
INTERNATIONAL JOURNAL OF ACADEMIC RESEARCH IN BUSINESS AND SOCIAL SCIENCES Vol. 10, No. 8, 2020, E-ISSN: 2222-6990 @ 2020 HRMARS

Table 4.1 Level of education

\begin{tabular}{lcc}
\hline Level of education & Frequency & Percent (\%) \\
\hline Certificate & 4 & 5.6 \\
Diploma & 5 & 7.0 \\
Degree & 18 & 25.4 \\
Post Graduate & 44 & 62.0 \\
Total & $\mathbf{7 1}$ & $\mathbf{1 0 0 . 0}$ \\
\hline
\end{tabular}

\section{Employment Tenure of Respondents}

The employment tenure of the respondents was also sought by this study. The period under which a respondent has been in the university intended to find out whether they are familiar with university financial processes. The results are presented in Table 4.2. The study revealed that majority of staff working as heads of sections in finance department and heads of departments from other departments had served the university for less than five years. Out of the 71 respondents $69 \%$ served for less than five years, $15.5 \%$ served between five to ten years, $9.9 \%$ served between eleven to fifteen years, $5.6 \%$ served for above fifteen years.

Table 4.2 Years have you been in university

\begin{tabular}{lcc}
\hline Years have you been in university & Frequency & Percent (\%) \\
\hline Below 5 years & 49 & 69.0 \\
5-10 years & 11 & 15.5 \\
$10-15$ years & 7 & 9.9 \\
15 years and above & 4 & 5.6 \\
Total & $\mathbf{7 1}$ & $\mathbf{1 0 0 . 0}$ \\
\hline
\end{tabular}

\section{Effect of Online Financial Documentation of Operating Cost}

The study sought to assess the effects of online financial documentation on operating cost. The respondents were required to indicate the extent to which specific aspects of online financial documentation affects operating cost. Table 4.3 shows that preparation of payment vouchers online was rated the highest cost saving parameter with a mean score $=4.62$, Writing and signing of RTGS online mean score $=4.47$, Generation of receipts online had a mean score $=4.22$ while Writing and signing of cheques online mean score $=3.78$. This can be explained by the fact that payments vouchers were previous filled on letter headed A4 size papers in triplicates which increased the cost of stationeries and printing to a greater extent. Furthermore, every form of payment is supported by a payment voucher. 
INTERNATIONAL JOURNAL OF ACADEMIC RESEARCH IN BUSINESS AND SOCIAL SCIENCES Vol. 10, No. 8, 2020, E-ISSN: 2222-6990 @ 2020 HRMARS

Table 4.3 Mean on online financial documentation

Online financial documentation $\quad$ N Mean Std. Error Std. Deviation

\begin{tabular}{|c|c|c|c|c|}
\hline $\begin{array}{ll}\text { Generation of receipts online reduces } \\
\text { university's }\end{array}$ & 58 & 4.22 & .08 & .594 \\
\hline $\begin{array}{l}\text { Preparation of payment vouchers online } \\
\text { impacts on the organization operating costs }\end{array}$ & 58 & 4.62 & .06 & .489 \\
\hline $\begin{array}{l}\text { Writing and signing of cheques online affects } \\
\text { the university's operating costs }\end{array}$ & 58 & 3.78 & .09 & .702 \\
\hline $\begin{array}{l}\text { Writing and signing of RTGS online impacts on } \\
\text { the university's operating cost. }\end{array}$ & 58 & 4.47 & .07 & .503 \\
\hline
\end{tabular}

\section{Online Financial Documentation Regression Model}

Regression analysis was conducted to establish the relationship between online financial documentation and operating cost. The two variables were regressed to generate a model. The model fitness is presented in Table 4.4. The results show that the $R$ value was 0.371 indicating that there is a slight positive relationship between online financial documentation and operating cost in universities in Kenya. The $R$ squared $\left(R^{2}\right)$ value of 0.138 shows that only $13.8 \%$ of the variations in operating cost is explained by variations in online financial documentation.

Table 4.4 Model Summary

\begin{tabular}{lcccc}
\hline Model & $\mathbf{R}$ & R Square & Adjusted R Square & Std. Error of the Estimate \\
\hline 1 & .371 & .138 & .125 & .35521 \\
\hline
\end{tabular}

a Predictors: (Constant), online financial documentation

The ANOVA for the regression model is presented in Table 4.5. This table shows that the model has an associated $F$ Value of 11.035 with $p$-value of $.001<p=.05$. These two statistics imply that the model is significant. This is an indication that online financial documentation has a significant effect on operating cost of university in Kenya at $5 \%$ level of significance.

Regarding the research question how online financial documentation services affect operating costs of univesities, this study concludes that operating costs marginally increases with increase in online financial documentation but the increase insignificant.

Table 4.5 ANOVA on Online Financial Documentation

\begin{tabular}{llccccc}
\hline Model & & Sum of Squares & df & Mean Square & F & Sig. \\
\hline 1 & Regression & 1.392 & 1 & 1.392 & 11.035 & .001 \\
& Residual & 8.706 & 69 & .126 & & \\
& Total & $\mathbf{1 0 . 0 9 9}$ & $\mathbf{7 0}$ & & & \\
\hline
\end{tabular}

a Predictors: (Constant), online financial documentation

b Dependent Variable: Operating cost 
INTERNATIONAL JOURNAL OF ACADEMIC RESEARCH IN BUSINESS AND SOCIAL SCIENCES Vol. 10, No. 8, 2020, E-ISSN: 2222-6990 @ 2020 HRMARS

The regression model coefficients were also generated. The results are presented in Table 4.6. Table 4.6 shows that the intercept of 4.254 and a slope of 0.07461 with a $p$ value of 0.001 . Considering online financial documentation as the predictor of operating cost shows that online financial documentation is significant with a $p$ - value of $.001<p=0.05$. Online financial documentation had a $\beta=0.371$. This means that a unit change in online financial documentation results into 7.461 times increase in Operating Costs in the University. These findings confirms earlier findings by Barata et al (2001) who found out that good practice for the management of financial records in computerized systems and analyses the optimal ways of creating the linkages between the manual (i.e. paperbased) and computerized parts of systems and provides tools to evaluate and monitor the performance of record keeping systems.

The finding concurs with Theory of planned behaviour (TPB) which states that the effective use of electronic financing is a deliberate action arising from employee's attitude towards adoption of efinancing, motivation levels from the management mainly perceived benefits and the extent to which they evaluate their ability to work with the system, that employees can plan deliberately to frustrate the e-financing if they do not understand how it will improve their performance or earnings or if they fear the change will force them to learn new skills which they are not willing to learn. Sharma and Ahuja (2014) observed that operating costs are the expenses which are related to the operations of a business, or to the operation of a device, component, and piece of equipment or facility.

Table 4.6 Regression coefficient on online financial documentation

\begin{tabular}{|c|c|c|c|c|c|c|}
\hline \multirow{2}{*}{\multicolumn{2}{|c|}{ Model }} & \multicolumn{2}{|c|}{$\begin{array}{l}\text { Unstandardized } \\
\text { Coefficients }\end{array}$} & \multirow{2}{*}{$\begin{array}{c}\begin{array}{c}\text { Standardized } \\
\text { Coefficients }\end{array} \\
\text { Beta }\end{array}$} & \multirow[t]{2}{*}{$\mathbf{t}$} & \multirow[t]{2}{*}{ Sig. } \\
\hline & & B & Std. Error & & & \\
\hline \multirow[t]{2}{*}{1} & (Constant) & 4.254 & .123 & & 34.628 & .000 \\
\hline & Online financial documentation 7 & $.461 \mathrm{E}-02$ & .022 & 371 & 3.322 & .001 \\
\hline
\end{tabular}

a Dependent Variable: Operating cost

\section{Effect of Online Electronic Financial Statements}

The study sought to assess the effects of online electronic financial statements on operating cost. The respondents were required to indicate the extent to which specific aspects of online electronic financial statements affects operating cost. Table 4.7 shows that generation of online statement of financial statement was highly rated as a way of reduction of operating cost with a mean score $=4.51$, Preparation of e-ledgers and e-journals mean score $=4.38$, Extraction of trial balances online mean score $=4.32$, Preparation of e-cash flow mean score $=4.08$. This can be explained by the fact that statement of financial statement gives the summary of all other financial statements and mostly are prepared periodically or when need arises thus it's not a routine practice. 
INTERNATIONAL JOURNAL OF ACADEMIC RESEARCH IN BUSINESS AND SOCIAL SCIENCES Vol. 10, No. 8, 2020, E-ISSN: 2222-6990 @ 2020 HRMARS

Table 4.7 Mean on Online electronic financial statements

\begin{tabular}{|c|c|c|c|c|}
\hline Online electronic financial statements & $\mathbf{N}$ & Mean & Std. Error & Std. Deviation \\
\hline $\begin{array}{l}\text { Preparation of e-ledgers and e-journals } \\
\text { impacts on the university's operating cost }\end{array}$ & 71 & 4.38 & .11 & .931 \\
\hline $\begin{array}{l}\text { Extraction of trial balances online reduces } \\
\text { the university's operating cost }\end{array}$ & 71 & 4.32 & .11 & .922 \\
\hline $\begin{array}{l}\text { Generation of online financial statement } \\
\text { reduces the university's operating cost }\end{array}$ & 71 & 4.51 & .08 & .673 \\
\hline $\begin{array}{l}\text { Preparation of e-cash flow affects the } \\
\text { university's operating cost }\end{array}$ & 71 & 4.08 & .08 & .649 \\
\hline
\end{tabular}

\section{Online Electronic Financial Statements Regression Model}

The study sought to establish the relationship between online electronic financial statements and on operating cost. The two variables were regressed to generate a model. The model fitness is presented in Table 4.8. The results show that the $R$ value was 0.018 indicating that there is a slight positive relationship between online electronic financial statements and operating cost in universities in Mount Kenya region. The $R$ squared $\left(R^{2}\right)$ value of 0.000 shows that none of the variations in operating cost is explained by variations in online electronic financial statements.

Table 4.8 Model Summary on Online electronic financial statements

\begin{tabular}{lcccc}
\hline Model & $\mathbf{R}$ & R Square & Adjusted R Square & Std. Error of the Estimate \\
\hline 1 & .018 & .000 & -.014 & .38250 \\
\hline
\end{tabular}

a Predictors: (Constant), Online electronic financial statements

The ANOVA for the regression model is presented in Table 4.9. This table shows that the model has an associated $F$ Value of 0.024 with $p$-value of $.878>p=.05$. These two statistics imply that the model is not significant. This is an indication that although online electronic financial statements have a slight positive effect on operating cost of a university, the effect is insignificant at $5 \%$ level of significance. Regarding the research question how online electronic financial statements affect operating costs of univesities, this study concludes that operating costs marginally increases with increase in online electronic financial statements but the increase in not significant.

Table 4.9 ANOVA on Online Electronic Financial Statements

\begin{tabular}{llccccc}
\hline Model & Sum of Squares & df & Mean Square & F & Sig. \\
\hline 1 & Regression & .003 & 1 & .003 & .024 & .878 \\
& Residual & 10.095 & 69 & .146 & & \\
& Total & $\mathbf{1 0 . 0 9 9}$ & $\mathbf{7 0}$ & & & \\
\hline
\end{tabular}

a Predictors: (Constant), Online electronic financial statements

b Dependent Variable: Operating cost

The regression model coefficients were also generated. The results are presented in Table 4.10. Table 4.10 shows that the intercept of 4.594 and a slope of 0.011 with a $p$ value of 0.878 . Considering online 
INTERNATIONAL JOURNAL OF ACADEMIC RESEARCH IN BUSINESS AND SOCIAL SCIENCES Vol. 10, No. 8, 2020, E-ISSN: 2222-6990 @ 2020 HRMARS

electronic financial statements as the predictor of operating cost shows that online electronic financial statements is insignificant with a $p-$ value of $0.878>p=0.05$. Online electronic financial statements had a $\beta=0.018$. This means that a unit change in online electronic financial statements results into 1.1 times increase in Operating Costs in the University. Sadagopan (2003), asserts that some of the most ordinary accounting processes, which are incorporated in an ERP system, include: general ledger, accounts receivable, accounts payable, financial control, asset management, funds flow, cost centers, profit centers. Though E-financial statements was found to have no major effect on operating costs of universities under this study, Stephenie Meyer (2008) asserts that financial institutions and all other institutions, whoever needs to send you a statement monthly, quarterly, or annually, are moving towards eliminating paper statements and encouraging customers to subscribe or access statements online thus reduce operating costs.

Table 4.10 Regression coefficient on online financial documentation

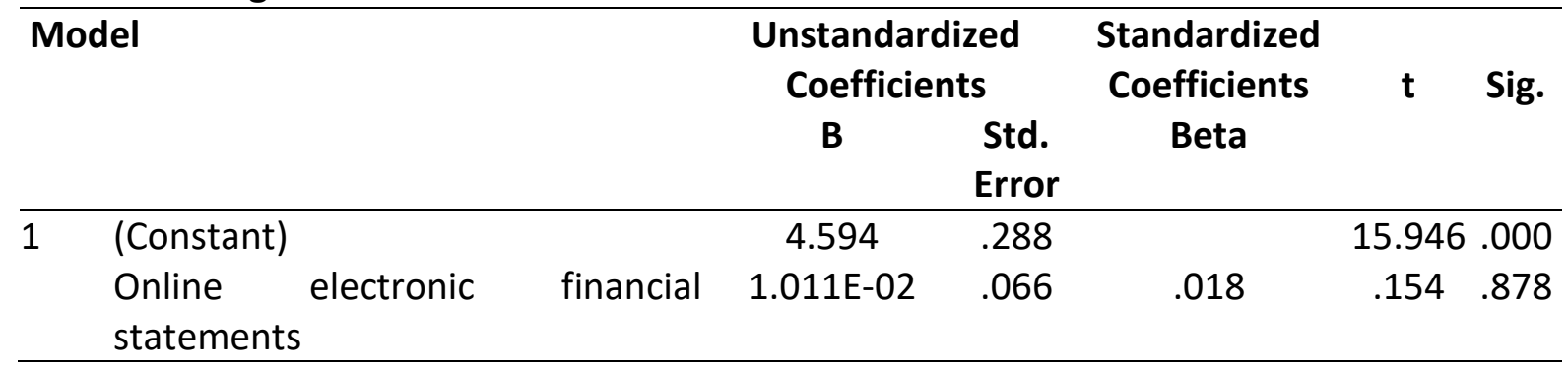

a Dependent Variable: Operating cost

Robinson (2000) who argued that the cost of an electronic financial transaction is dramatically less when done online as compared to when done manually.

Shah (2011) noted that ERP has been used to gaining competitive advantage and reduce costs by improving its overall efficiency in managing inventory and sales. King, Kvavik, and Voloudakis (2002) argued that some of the top reasons universities adopt ERP solutions are to replace legacy systems, improve customer service, and transform enterprise processes, correct year 2000 problems, modernize computer systems, improve administration, maintain competitiveness, increase operating efficiency, and adhere to regulatory compliance. Nah and Kuang (2001) argued that the major goal of ERP is to increase operating efficiency by improving business processes and decreasing costs. Leech and Grabski (2007) identified the relation of ERP system on financial performance of the business.

\section{Conclusions and Recommendations}

Based on the study findings, the study conclude that electronic financial documentation was found to be statistically significance and had an influence on the operating cost. Electronic financial documentation was considered in terms of preparation of payment vouchers, writing and signing of RTGS, generation of receipts, writing and signing of cheques online. Preparation of payment vouchers online was rated the highest aspect that may reduce operating cost significantly. The study further conclude that electronic financial statements were found to had statistically is significance effect on the operating cost of universities. Electronic financial statements were considered in terms of generation of online statement of financial statement, preparation of e-ledgers and e-journals, 
INTERNATIONAL JOURNAL OF ACADEMIC RESEARCH IN BUSINESS AND SOCIAL SCIENCES Vol. 10, No. 8, 2020, E-ISSN: 2222-6990 @ 2020 HRMARS

extraction of trial balances online, preparation of e-cash flow. Generation of online of financial statement was highly rated as a significant as it would lead to reduction of operating cost.

Based on the study findings, this study recommends that that the universities in Kenya should automate of financial services because it enhances financial performance of the organization. In addition, organizations should continuously improve their electronic financial processes to enable the system to generate electronic financial statements because they considerably reduce the operating costs. The research as well recommends collaboration between program designers and the end-users of financial software. The study further recommends top management should support the staff as they transit from manual to electronic financing

\section{Areas of Further Studies}

It is important to note that this research has filled a lot of gaps left by previous researchers. However, due to limitations, this research was not able to cover some areas. It therefore recommended that further study should focus on the effects of inadequate employees' financial skills on the operating costs of an organization. Moreover, future researcher should also evaluate the role of management in controlling organization operating costs.

\section{References}

Ajzen, I., \& Fishbein, M. (1980), Understanding attitudes and predicting social behavior. Englewood Cliffs, NJ: Prentice-Hall.

Allen, F. (1999), What Do Financial Intermediaries Do? University of Philadelphia, Philadelphia, Penn. Allen, F., McAndrews, J., and Stratran, P. (2002), "E-finance: an introduction", Journal of Financial Services Research, Vol. 22 Nos. 1-2, pp. 5-27.

Bailey, M. (2004), Retail Payments in Selected Countries: A Comparative Study, Switzerland, Basel .International Journal of Bank Marketing, Vol. 17 No.2, 1999 pp.72-82 Mols, 1998

Bamford, D. R., \& Land, N. (2006), The application and use of the PAF quality costing model within a footwear company. The International Journal of Quality \& Reliability Management. Vol 23. Iss 2/3. pp $265-278$

Barata, Kimberly and Piers Cain, (2001), 'Information, Not Technology, is Essential to Accountability: Electronic Records and Public Sector Financial Management.' Information Society

Borg, R. W., and Gall, M. D. (2008), Education Research: An Introduction. New York: Longman Inc

Bushman, R., Engel, E., Milliron, J., and Smith, A. (2001), An analysis of the relation between the Stewardship and valuation roles of earnings. Working Paper, University of Chicago Plunkett, $\mathrm{S}$. (1979). Decomposition and all that rot. Mathematics in School, 8, 2-5

Dillard, J. F., \& Yuthas, K. (2006), Enterprise resource planning systems and communicative action. Critical Perspectives on Accounting, 17(2), 202-223.

Esteves, J., \& Bohorquez, V. (2007). An Updated ERP System Annotated Bibliography: 2001-2005. Communication of the Association for Information Systems (CAIS), Volume 19, Article 18, April, 2007.

Frantz, R. (2002), John Stuart mill as an anti-intuitionist social reformer. The Journal of SocioEconomics, 31(2), 125-136.

Gaffey, A. D. (2009), Communication and documentation considerations for electronic health records. J of Healthcare Risk Mgmt, 29, 16-20. doi: 10.1002 
INTERNATIONAL JOURNAL OF ACADEMIC RESEARCH IN BUSINESS AND SOCIAL SCIENCES

Vol. 10, No. 8, 2020, E-ISSN: 2222-6990 @ 2020 HRMARS

Gupta, S. P., Sharma A., and Ahuja, S. (2014), Cost Accounting. FK Publications. New Delhi.

King, P., Kvavik, A., and Voloudakis, J. (2002), Enterprise resource planning systems in higher education. Centre for Applied Research Bulletin. 22, 1-11.

Kombo, D. K., \& Tromp, D. L. A. (2006), Proposal \& Thesis Writing: An Introduction_2 ${ }^{\text {nd }}$ ed. Paulines Publications Africa, Nairobi.

Lockwood, G., \& Davies, J. L. (1985), Universities: The management challenge Society or Research into Higher Education.

Maggiotto, R. (2000), Defining Tomorrows Leading Financial Services Institution, Pricewaterhouse Coopers, Global Financial Services Leadership Team, New York.

Maroofi, F. (2012), Impact of enterprise resource planning systems on company performance and management control systems. International Journal of Business Environment. 5. 51 - 73. 10.1504/IJBE.2012.044928.

Marshall, C., \& Rossman, G. B. (2011), Designing Qualitative Research (5 $5^{\text {th }}$ ed.). London. Sage Publications.

Miller, R. H., \& Sim, I. (2004), Physicians' use of electronic medical records: Barriers and solutions. Health Affairs, 23(2), 116-126.

Miriam P., (2000), International Banking and Financial Market Developments, Quarterly Review, Switzerland, Basel.

Mugenda, M., \& Mugenda, A. (2008), Research Methods: Quantitative and Qualitative approaches, African centre for Technology Studies, Nairobi.

Ogula, D. (2008). Attractors, strange attractors and fractals. Encyclopedia of Public Administration and Public Policy, Second Edition (Print Version).Evan M. Berman, (Ed.). Boca Raton, FL: CRC Press, pp. 118-122.

Orodho, J. A. (2009), Techniques of writing research proposals and report in education and social sciences. Nairobi: Masola Publishers.

Rabaa'i, A. A., Bandara, W., \& Gable, G. (2009), ERP systems in the higher education sector: A descriptive study. Proceedings of the 20th Australasian Conference on Information Systems, 456-470.

Robinson, T. (2000), "Internet banking - still not a perfect marriage", Information week, Vol.17, No. 4, 104-106.

Sadagopan, S. (2003), "Enterprise resource planning”, Encyclopedia of Information Systems, Vol. 2, pp. 169-184

Sale, M. L. (2005), An Analysis of the Influence of ERP Implementation on Financial Accounting Measures. Allied Academies International Conference (pp. 73-77). Proceedings of the Academy of Accounting and Financial Studies.

Shahrokhi, M. (2008), E-finance: status, innovations, resources and future challenges, Managerial Finance, 34(6), 365-398

Swartz, D., \& Orgill, K. (2001), Higher education ERP: Lessons learned. Educause Quarterly, 24(2), 2027. 